\title{
SERUM LIPIDS AND GLUCOSE DISTURBANCES AT PROFESSIONAL DRIVERS EXPOSED TO OCCUPATIONAL STRESSORS
}

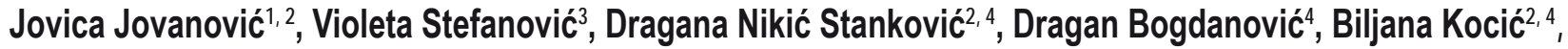 \\ Milan Jovanović2 ${ }^{2}$ Zorica Antić ${ }^{2}$, Maja Nikolić2, ${ }^{2}$, Jovana Jovanović ${ }^{2}$ \\ ${ }^{1}$ Institute of Occupational Health Niš, Serbia \\ ¿University of Niš, Medical Faculty Niš, Serbia \\ ${ }^{3}$ Public Health Centre Kuršumlija, Serbia \\ ${ }^{4}$ Public Health Centre Niš, Serbia
}

\begin{abstract}
SUMMARY
The aim of this study is to find association between some groups of occupational stressors and serum lipids and glucose concentrations in professional drivers in road traffic. The study included 417 male professional drivers (162 inter city bus drivers, 36 suburban bus drivers, 33 city bus drivers, 81 truck drivers, 71 official car drivers and 34 professional taxi drivers). Occupational stressors were identified and total occupational stress index score was measured by standardized questionnaire authorized by Karen Belkic. Occupational stressors were divided into seven groups (underload, high demand, strictness, extrinsic time pressure, noxious exposures, avoidance and conflict). Serum glucose and lipids concentrations (total cholesterol, LDL cholesterol, HDL cholesterol and triacylglycerols) were measured in study group of drivers. Maximal total OSI values were achieved in group of professional truck drivers. The highest values of serum glucose, total cholesterol, LDL cholesterol and triacylglycerols and the lowest values of serum HDL cholesterol were found at professional truck drivers. With the increase of occupational stress index, there is an increase of the serum glucose, total cholesterol, LDL cholesterol and triacylglycerols concentration in the exposed group of drivers. Specific analytes thresholds' level of occupational stress index exists.
\end{abstract}

Key words: glucose, cholesterol, triacylglycerols, occupational stress index, professional drivers

Address for correspondence: J. Jovanović, Vidoja Jovanovića 30, 18205 Niška Banja, Serbia. E-mail: joca@medfak.ni.ac.yu, drjovicajovanovic@yahoo.com

\section{INTRODUCTION}

Although occupational stress is by no means a new phenomenon, it is becoming increasingly globalized and affects both blue and white collar workers as well as families and society in general. Stress at work is in constant expansion and it presents an increasing medical and economical problem $(1,2,3,4)$. Stress is often described as "a variance between workload and capability". The workload may be greater than the capability of the individual or the workload may be less than the individual's capability. Excessive stress can manifest itself in physical, emotional or behavioral effects. These effects are usually short-lived and cause no lasting harm. When the pressures recede, there is a quick return to normal. Stress is not therefore the same as ill health. It is only when pressures are intense and continue for some time that the effects of stress can become more sustained and far more damaging leading to longer term psychological problems and physical ill health $(1,4)$.

The aim of this study is to find correlations between some groups of occupational stressors and serum lipids concentrations in exposed professional drivers coping with road traffic. This paper aimed to examine the effect of the professional stressors load at work of professional drives in road traffic on the concetration of total cholesterol, triacylglycerols, HDL cholesterol and LDL cholesterol.

\section{MATERIALS AND METHODS}

The research involved a group of 417 male professional drivers who were divided into six subgroups (162 inter city bus drivers, 36 suburban bus drivers, 33 city bus drivers, 81 truck drivers, 71 official car drivers and 34 professional taxi drivers). The presence and intesity of some stressors was investigated by the application of a standardized questionnaire and the calcuation of the total stressors load index on drivers at work was done (5). The occupational stress index was calculated using the standardized questionnaire authorized by Karen Belkic (5). According to cited author the occupational stressors were divided into the seven groups (high demands, 
strictness, underload, extrinsic time pressure, noxious exposure, avoidance and conflict). High demands present heterogeneous information, high frequency of incoming signals ( $>5$ new signals per minute), heterogeneous tasks, two or more jobs, visual perception, making complex decisions, different procedures, simultaneous performance of complex, quick and different tasks, considering information to be processed, making rapid decisions and necessity to communicate at work. High demands also mean salary according to efficiency, long work hours, not enough rest breaks, work in different places, day and night work shifts, lack of paid vacation. Strictness can be seen in the limitations of problem solving strategy, strict accuracy in defining decisions, strict evaluation of performance, workspace limitations, shortage of autonomous workspace, limited influence on duties, limited influence on the work process, strict supervision according to rigid rules, the need to carry out duties according to strictly defined standards, fixed body posture at work, job performance in a restricted, cramped workspace and lack of autonomous workspace.

As an element of drivers' occupational stress index is underload which represents reception of homogenous information or sparse signals, low frequency of incoming signals $(<1$ signal/ minute), working alone without any communiction with other people at work, fixed or inadequate pay, lack of promotion prospects, lack of recognition for good work, homogeneous and simple tasks. Extrinsic time pressure represents the need to speed up work and time limitation for performing the job, control of incoming signals, decisions which cannot be postponed, control of task performance rate and deadline pressure. Noxious exposures include isometric lifting, exposure to glare, light, flash, noise, vibrations, heat, cold, gases, fumes and dust. Avoidance means being on constant alert so as to avoid possible consequences, being present at visually disturbing scenes, accidents or emotionally disturbing events, and experiencing a car crash, hazardous task performance, work accidents or injuries, and lack of functioning emergency system. Conflict respresents a lack of relevant information for making decisions, receveing contradictory information, confrontation with unexpected events which demand a change of the existing working plan, and thus creating conflict and uncertainty when making decisions.

There are also conflict demands in time and space, conflict demands because of external problems and work interruptions by associates or other people. Conflicts generate when the working atmosphere is overloaded with tension and intepersonal conflicts, when there is not enough colleagues' support, when there is opposition to career promotion, unstable working conditions and when there is a threath of job loss. The burden of stressors in the professional drivers work environment was assessed. The «Occupational Stress Index » (OSI) questionnaire for drivers was used in a cross sectional prevalence study design. A sample of vein blood was taken from all drivers in the morning after twelve hour food abstinence. The total cholesterol, triacylglycerols, HDL cholesterol and LDL cholesterol were determined by standard methods. Serum lipid analytes (total cholesterol, HDL cholesterol, LDL cholesterol, triacylglycerols) were examined by standard methods. Kolmogorov-Smirnov test did not confirm normal distributional characteristic of any working variable. ANOVA derived from general linear model with Dunnett post hoc test was performed to compare parameter values between groups. Logistic regression was used to examine the associations between categories of exposure (OSI) and categories of outcome, adjusted for age and smoking status.

\section{RESULTS}

The results show that professional drivers are a heavily burdened occupational group. The total OSI for all groups of professional drivers was $63.9 \pm 8.8$ ( $43.2 \%$ of maximum load). Stressors from the high demands group prevail in professional drivers (index $15.6 \pm 1.8)(39.0 \%$ of maximum load). Maximal total OSI values were achieved in group of professional truck drivers (71.1 points of total OSI). Suburban bus drivers had the lowest level of the total professional stressors burden in relation to other groups of professional drivers. The highest values of serum glucose, total cholesterol, LDL cholesterol and triacylglycerols and the lowest values of serum HDL cholesterol were found at professional truck drivers (Table 1). Logistic regression analysis shows the statistical significantly odds ratios between total occupational stress index and serum glucose $(\mathrm{p}<0.05)$, total cholesterol $(\mathrm{p}<0.001)$, LDL cholesterol $(\mathrm{p}<0.001)$ and triacylglycerols $(p<0.001)$. Increasing total occupational stress index is associated with larger analyte range. With the increase of occupational stress index, there is an increase of the serum glucose concentration in the exposed group of workers. This association is more evident over a tresholds' level of OSI for glucose (90 points of total OSI) (Fig. 1). Following the increase of the OSI values, the level of

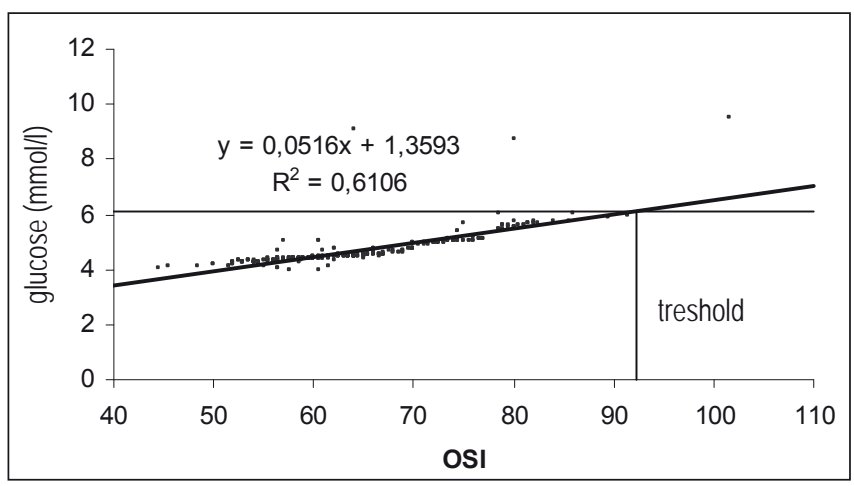

Fig. 1. The relation between OSI values and serum glucose concentrations.

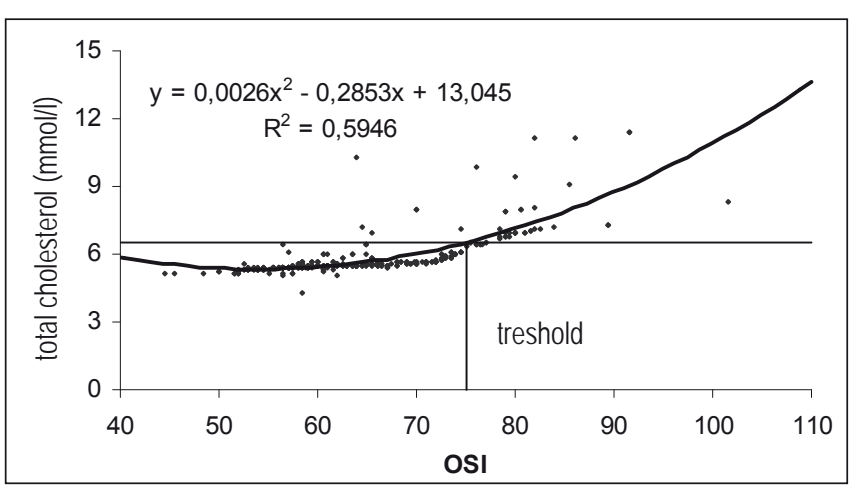

Fig. 2. The relation between OSI values and serum total cholesterol concentrations. 
Table 1. Occupational stress index and blood levels of lipids and glucose in the examined group (mean $\pm S D)$

\begin{tabular}{|c|c|c|c|c|c|c|c|c|}
\hline $\begin{array}{l}\text { Stressors } \\
\text { (max. load value } \\
\text { index) }\end{array}$ & $\begin{array}{l}\text { City bus } \\
\text { drivers }\end{array}$ & $\begin{array}{l}\text { Inter city } \\
\text { bus drivers }\end{array}$ & $\begin{array}{l}\text { Truck } \\
\text { drivers }\end{array}$ & $\begin{array}{c}\text { Official } \\
\text { car drivers }\end{array}$ & $\begin{array}{l}\text { Suburban } \\
\text { bus drivers }\end{array}$ & $\begin{array}{l}\text { Professional } \\
\text { taxi drivers }\end{array}$ & Total & $\begin{array}{c}\text { Global } \\
\text { statistics for } \\
\text { differences }^{\circ}\end{array}$ \\
\hline High demands (40) & $15.9 \pm 1.7$ & $15.5 \pm 1.9$ & $15.7 \pm 2.6$ & $15.5 \pm 1.7$ & $15.0 \pm 1.9$ & $15.3 \pm 2.1$ & $15.6 \pm 1.8$ & A† \\
\hline Strictness (20) & $12.0 \pm 2.0$ & $12.0 \pm 1.8$ & $12.8 \pm 1.0$ & $11.9 \pm 1.5$ & $10.9 \pm 1.1$ & $12.3 \pm 2.8$ & $11.9 \pm 1.8$ & 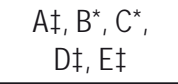 \\
\hline Conflict (30) & $12.4 \pm 3.9$ & $12.8 \pm 4.2$ & $15.2 \pm 3.8$ & $11.6 \pm 2.8$ & $9.7 \pm 2.6$ & $11.5 \pm 3.5$ & $11.9 \pm 3.7$ & $\begin{array}{c}\mathrm{A} \ddagger, \mathrm{B} \dagger, \mathrm{C} \dagger, \mathrm{D} \ddagger, \\
\mathrm{E} \neq, \mathrm{F}^{*}\end{array}$ \\
\hline Underload (20) & $2.4 \pm 1.4$ & $2.3 \pm 1.1$ & $3.2 \pm 1.2$ & $2.6 \pm 1.0$ & $2.4 \pm 1.0$ & $1.7 \pm 1.1$ & $2.5 \pm 1.3$ & ns \\
\hline Avoidance (18) & $8.0 \pm 1.6$ & $8.6 \pm 1.9$ & $8.4 \pm 2.2$ & $8.0 \pm 1.6$ & $7.6 \pm 1.4$ & $7.8 \pm 0.3$ & $8.0 \pm 1.7$ & ns \\
\hline $\begin{array}{l}\text { Extrinsic time pres- } \\
\text { sure (10) }\end{array}$ & $8.8 \pm 0.6$ & $8.8 \pm 0.6$ & $8.9 \pm 0.4$ & $8.5 \pm 0.9$ & $8.7 \pm 1.2$ & $7.7 \pm 1.1$ & $8.7 \pm 0.8$ & ns \\
\hline $\begin{array}{l}\text { Noxious exposures } \\
\text { (10) }\end{array}$ & $4.7 \pm 2.1$ & $5.6 \pm 2.8$ & $6.7 \pm 2.7$ & $6.1 \pm 2.3$ & $4.6 \pm 1.6$ & $6.2 \pm 3.7$ & $5.2 \pm 2.3$ & $D^{\star}, E \ddagger, F^{\star}, G \ddagger$ \\
\hline Total (148) & $64.4 \pm 8.9$ & $65.7 \pm 9.7$ & $71.1 \pm 10.5$ & $64.2 \pm 7.0$ & $59.0 \pm 6.5$ & $61.5 \pm 9.8$ & $63.9 \pm 8.8$ & $\mathrm{~A} \ddagger, \mathrm{B} \dagger, \mathrm{D} \ddagger, \mathrm{E} \ddagger$ \\
\hline \multicolumn{9}{|l|}{ ANALYTES } \\
\hline Glucose & $4.7 \pm 0.5$ & $4.7 \pm 0.5$ & $5.1 \pm 1.1$ & $4.6 \pm 0.4$ & $4.5 \pm 0.6$ & $4.5 \pm 0.4$ & $4.6 \pm 0.6$ & ns \\
\hline Total cholesterol & $5.9 \pm 1.0$ & $5.9 \pm 1.2$ & $6.0 \pm 0.8$ & $5.7 \pm 0.8$ & $5.5 \pm 0.6$ & $5.4 \pm 0.2$ & $5.8 \pm 0.9$ & A† \\
\hline $\mathrm{HDL}$ & $123.3 \pm 31.4$ & $118.2 \pm 35.3$ & $109.4 \pm 32.6$ & $126.1 \pm 26.8$ & $140.2 \pm 18.3$ & $126.7 \pm 19.4$ & $125.7 \pm 29.8$ & $\mathrm{~A} \ddagger, \mathrm{B} \dagger, \mathrm{D} \dagger, \mathrm{E} \dagger$ \\
\hline LDL & $3.7 \pm 1.0$ & $3.8 \pm 1.2$ & $4.1 \pm 1.0$ & $3.6 \pm 0.9$ & $3.3 \pm 0.6$ & $3.3 \pm 0.3$ & $3.6 \pm 0.9$ & $A \dagger, D^{*}$ \\
\hline Triacylglycerols & $2.0 \pm 1.3$ & $2.1 \pm 1.3$ & $2.5 \pm 1.6$ & $1.8 \pm 1.0$ & $1.5 \pm 0.9$ & $1.4 \pm 0.2$ & $1.9 \pm 1.2$ & $A^{*}$ \\
\hline
\end{tabular}

NOTE: ${ }^{-}$- ANOVA derived from general linear model with Dunnett's T3 post hoc test; * ${ }^{*} p<0.05 ; \dagger-p<0.01 ; \ddagger-p<0.001$

A - city bus drivers vs. suburban bus drivers; B - intercity bus drivers vs. suburban bus drivers; C - truck drivers vs. official car drivers; D - truck drivers vs. suburban bus drivers; E - official car drivers vs. suburban bus drivers; F - city bus drivers vs. truck drivers; G - city bus drivers vs. official car drivers; ns - non significant.

serum total cholesterol in the exposed group of workers grows. This association is more evident with over a tresholds' level of OSI for total cholesterol (75 points of total OSI) (Fig. 2). Higher OSI values are followed by increasing serum LDL cholesterol values in the exposed group of workers. This association is more evident over a tresholds' level of OSI for LDL cholesterol (70 points of total OSI) (Fig. 3). While the OSI values increase, concetrations of serum triacylglycerols increase in exposed group of workers. This association is more evident over a tresholds' level of OSI for triacylglycerols (65 points of total OSI) (Fig. 4).

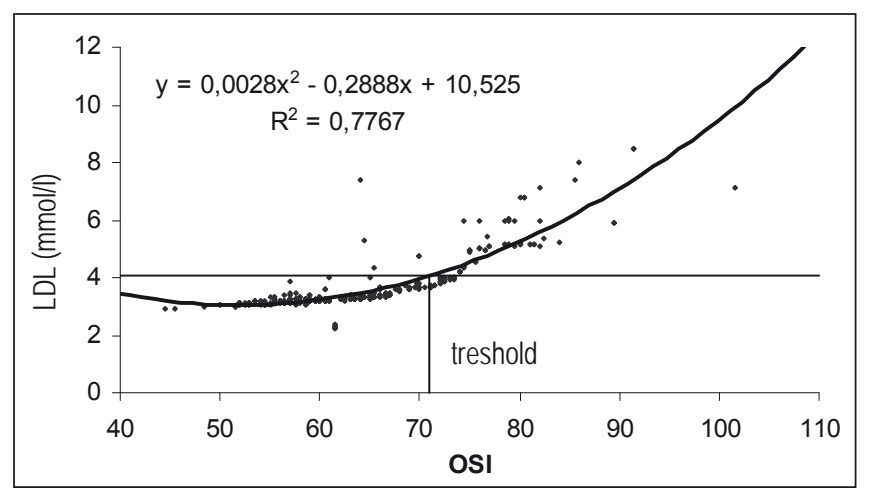

Fig. 3. The relation between OSI values and serum LDL concentrations.

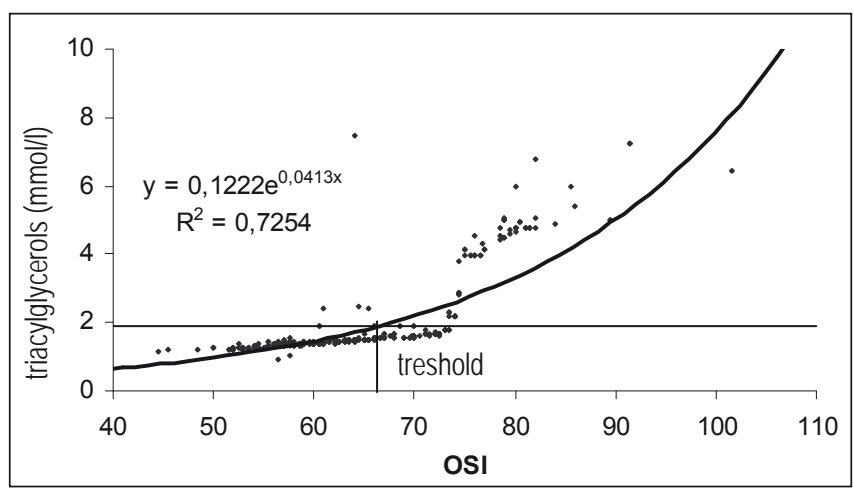

Fig. 4. The relation between OSI values and serum triacylglycerols concentrations.

\section{DISCUSSION}

Professional stress is a result of the work process or working enviroment factors effect followed by an adjustment reaction and subsequent different psychological and physical disorders (6-10). This research has determined that the most common stressful factors in work places of professional drivers are high demands, strictness, underload, extrinsic time pressure, conflict and noxious esposures. These results are in concordance with research of other authors who studied work conditions and working environment of drivers (11-15). All of these increase tension at work and decrease 
Table 2. Odds ratios and 95\% confidence intervals for glucose and serum lipid disturbance, by stressor, logistic regression

\begin{tabular}{|l|c|c|c|c|c|}
\hline \multirow{2}{*}{ Stressors } & \multicolumn{5}{|c|}{ Odds ratios and 95\% confidence intervals } \\
\cline { 2 - 7 } & $\begin{array}{c}\text { Glucose } \\
(>6.1 \mathrm{mmol} / \mathrm{l})\end{array}$ & $\begin{array}{c}\text { Total cholesterol } \\
(>6.5 \mathrm{mmol} / \mathrm{l})\end{array}$ & $\begin{array}{c}\text { HDL } \\
(<1.55 \mathrm{mmol} / \mathrm{l})\end{array}$ & $\begin{array}{c}\text { LDL } \\
(>4.1 \mathrm{mmol} / \mathrm{l})\end{array}$ & $\begin{array}{c}\text { Triacylglycerols } \\
(>1.88 \mathrm{mmol} / \mathrm{l})\end{array}$ \\
\hline High demand & $3.12(1.30,7.47)^{\star}$ & $2.19(1.61,2.97)^{\ddagger}$ & $0.83(0.27,2.53)$ & $1.94(1.52,2.49)^{\ddagger}$ & $1.97(1.56,2.49)^{\ddagger}$ \\
\hline Underload & $1.57(0.92,2.69)$ & $1.48(1.15,1.90)^{\ddagger}$ & $0.66(0.15,3.03)$ & $1.38(1.09,1.73)^{\dagger}$ & $1.33(1.07,1.67)^{\dagger}$ \\
\hline Strictness & $0.98(0.46,2.12)$ & $3.24(2.14,4.91)^{\ddagger}$ & $0.70(0.13,3.62)$ & $3.48(2.36,5.14)^{\ddagger}$ & $3.21(2.28,4.53)^{\ddagger}$ \\
\hline Avoidance & $1.95(1.06,3.60)^{\star}$ & $1.57(1.25,1.96)^{\ddagger}$ & $1.44(0.48,4.34)$ & $1.75(1.40,2.17)^{\ddagger}$ & $1.57(1.29,1.92)^{\ddagger}$ \\
\hline Extrinsic time pressure & $0.86(0.06,12.58)$ & $1.04(0.68,1.58)$ & $0.88(0.13,5.69)$ & $1.16(0.79,1.71)$ & $1.27(0.86,1.86)$ \\
\hline $\begin{array}{l}\text { Noxious } \\
\text { exposure }\end{array}$ & $0.99(0.61,1.59)$ & $1.44(1.22,1.71)^{\ddagger}$ & $0.51(0.13,1.96)$ & $1.36(1.18,1.56)^{\ddagger}$ & $1.32(1.16,1.50)^{\ddagger}$ \\
\hline Conflict & $1.18(0.88,1.58)$ & $1.69(1.44,1.99)^{\ddagger}$ & $0.83(0.44,1.56)$ & $1.92(1.60,2.30)^{\ddagger}$ & $1.66(1.45,1.90)^{\ddagger}$ \\
\hline OSI total & $1.16(1.02,1.30)^{\star}$ & $1.52(1.33,1.75)^{\ddagger}$ & $0.84(0.55,1.28)$ & $1.77(1.46,2.14)^{\ddagger}$ & $1.47(1.32,1.62)^{\ddagger}$ \\
\hline
\end{tabular}

NOTE: Adjusted for age and smoking status. Limits for normal levels of analytes: glucose $<6.1 \mathrm{mmol} / \mathrm{l}$, total cholesterol $<6.5 \mathrm{mmol} / \mathrm{l}$, $\mathrm{HDL}>1.55 \mathrm{mmol} / /$, $\mathrm{LDL}<4.1 \mathrm{mmol} / \mathrm{l}$, triacylglycerols $<1.88 \mathrm{mmol} / \mathrm{l}$.

* $-p<0.05,{ }^{\dagger}-p<0.01,{ }^{\ddagger}-p<0.001$

work satisfaction, thus increasing the risk of bringing about lipid metabolism disturbance.

The obtained average values of the total professional stress index for drivers of all subgroups are high, which means that all these groups have, according to the bibliography, high levels of total occupational stressors' burden (16). According to these data, we can conclude that professional drivers are exposed to significant occupational risks. We have determined existance of statistically significant difference in the total OSI index value between the examined subgroups of professional drivers. This resulted in statistically significant differences in average values of serum lipid parameter concentration among these groups. We have also determined that serum lipid analytes depend on the stressors' burden index at work place. Professional drivers exposed to a greater stress index at work place had higher serum values of glucose, total cholesterol, triacylglycerols, LDL cholesterol and lower values of HDL cholesterol. These changes were identified as a main risk factor leading to ischemic heart disease $(17,18)$. Stressors lead to an increased secretion of catecholamines, glucocorticoids and mineralocorticoids. For example, very high excretion rates of adrenaline, noradrenaline, and 11-hydroxycorticosteroids were found in occupational groups working under high mental stress, high psychological demands, high responsibility, making important managing decisions and low job control (leading radio editors, responsible engineers and operators in nuclear power station, teachers in secondary schools, designing engineers) (19). Due to mutual action of catecholamines and glucocorticoids $\beta_{1}$ and $\beta_{2}$ receptors are stimulated in fat tissue, resulting in the increased lipolysis and vasodilatation in fat tissue which results in the increased concentration of free fatty acids from which cholesterol and triacylglycerols are synthesized. Catecholamines also inhibit the serum lipoprotein lipase activity (20) which under normal conditions breaks down triacylglycerols and very low density lipoproteins promoting the creation of high density lipoproteins (HDL cholesterol). When the activity of this enzyme is decreased, the concentration of triacylglycerols is increased and HDL choles- terol concetration is decreased. Such results were also confirmed by animal experiments which showed that chronical exposure to stressors leads to the increasing concentration of cholesterol in blood, also to the increasing piling up of cholesterol in tissues and to a greater degree of atherosclerotic lesion (21). There is more and more evidence that particular professional stressors cause increased production of free radicals which lead to increased lipid peroxidation and lipid metabolism disturbances (22).

\section{CONCLUSION}

The results of this work show that stress at work causes significant changes in the serum of the exposed professional drivers. These changes are in the form of the icreasing glucose concentration, total cholesterol, triacylglycerols, LDL cholesterol and decreasing HDL cholesterol concentration. Specific analytes thresholds' level of occupational stress index exists.

\section{REFERENCES}

1. Szymanski EM. Disability, job stress, and the changing nature of careers, and the career resilience portfolio. Rehabil Couns Bull. 1999 Apr;42(4):279-89.

2. Santos SR, Cox K. Workplace adjustment and intergenerational differences between matures, boomers, and xers. Nurs Econ. 2000 JanFeb;18(1):7-13.

3. Murphy GC, Athanasou JA. The effect of unemployment on mental health J Occup Organ Psychol. 1999 Mar;72(1):83-99.

4. Hidaka I, Ando S, Shigematsu H, Sakai K, Setoguchi S, Seto T, et al Noise-enhanced heart rate and sympathetic nerve responses to oscillatory lower body negative pressure in humans. J Neurophysiol. 2001 Aug;86(2):559-64

5. Belkić K. The Occupational stress index: an approach derived from cognitive ergonomics and brain research for clinical practice. Cambridge: Cambridge International Science Publishing; 2003.

6. Anshel MH. A conceptual model and implications for coping with stressful events in police work. Crim Justice Behav. 2000 Apr;27(3):375-400. 
7. Pflanz S. Psychiatric illness and the workplace: perspectives for occupational medicine in the military. Mil Med. 1999 Jun;164(6):401-6.

8. Alonzo AA. The experience of chronic illness and post-traumatic stress disorder: the consequences of cumulative adversity. Soc Sci Med. 2000 May;50(10):1475-84

9. Minter SG. Too much stress? Occup Hazard. 1999 May;61(5):49-52

10. Jovanović J, Jovanović M. Occupational stress and arterial hypertension. Med Pregl. 2004 Mar-Apr;57(3-4):153-8. (In Serbian.)

11. Chan KB, Lai G, Ko YC, Boey KW. Work stress among six professional groups: the Singapore experience. Soc Sci Med. 2000 May;50(10):141532.

12. Hetrick RL. Analyzing the recent upward surge in overtime hours. Month Lab Rev. 2000 Feb;123(2):30-3.

13. Schabracq MJ, Cooper C. The changing nature of work and stress. J Manag Psychol. 2000 Aug;15(3):227-41.

14. Dainoff MJ, Aarås A, Horgen G, Konarska M, Larsen S, Thoresen M, et al; MEPS Study Group. The effect of an ergonomic intervention on musculoskeletal, psychosocial and visual strain of VDT entry work: organization and methodology of the international study. Int J Occup Saf Ergon. 2005 Jan;11(1):9-23.

15. Levi L, Bartley M, Marmot M, Karasek R, Theorell T, Siegrist J, et al. Stressors at the workplace: theoretical models. Occup Med. 2000 JanMar;15(1):69-106.

16. Schnall PL, Belkić K, Landsbergis PA, Baker D, editors. The workplace and cardiovascular disease. Occup Med. 2000 Jan -Mar;15(1):24-46.
17. Kodat V, Sobota J, Kebza V, Biganovský M, Amortová R, Fischer J. Correlations of somatophysiological, biochemical, psychosocial and behavioral risk factors of cardiovascular diseases in a sample of employees of Prague enterprises and institutions. Cent Eur J Public Health. 2005 Dec;13(4):191-9.

18. Panagiotakos DB, Chrysohoou C, Pitsavos C, Antoniou S, Vavouranakis E, Stravopodis $\mathrm{P}$, et al. The association between occupational stress and the risk of developing acute coronary syndromes: the CARDIO2000 Study. Cent Eur J Public Health. 2003 Mar;11(1):25-30.

19. Vangelova $K$. The excretion rates of stress hormones under mental work. Cent Eur J Public Health. 2005 Mar;13(1):47-50.

20. Saiki A, Oyama T, Endo K, Ebisuno M, Ohira M, Koide N, et al. Preheparin serum lipoprotein lipase mass might be a biomarker of metabolic syndrome. Diabetes Res Clin Pract. 2007 Apr;76(1):93-101.

21. Carnicer R, Navarro MA, Arbonés-Mainar JM, Acín S, Guzmán MA, Surra JC, et al. Folic acid supplementation delays atherosclerotic lesion development in apoE-deficient mice. Life Sci. 2007 Jan 23;80(7):63843.

22. Julier K, Mackness MI, Dean JD, Durrington PN. Susceptibility of lowand high-density lipoproteins from diabetic subjects to in vitro oxidative modification. Diabet Med. 1999 May;16(5):415-23.

Received September 17, 2007 Accepted in revised form February 19, 2008 